\title{
Differential Expression of Redox Factor-1 Associated with Beta-Amyloid- Mediated Neurotoxicity
}

\author{
Zhiqun Tan ${ }^{*, \$,}$, Lei Shi ${ }^{\S, \dagger, 1}$ and Steven S. Schreiber ${ }^{1,2,3}$
}

\author{
Departments of ${ }^{1}$ Neurology, ${ }^{2}$ Anatomy and Neurobiology, University of California Irvine School of Medicine, Irvine, CA \\ 92697, USA; ${ }^{3}$ VA Long Beach Healthcare System, Long Beach CA 90822, USA
}

\begin{abstract}
Redox factor-1 (Ref-1), also known as HAP1, APE or APEX, is a multifunctional protein that regulates gene transcription as well as the response to oxidative stress. By interacting with transcription factors such as AP-1, NF-kappaB and p53, and directly participating in the cleavage of apurininic/apyrimidinic DNA lesions, Ref-1 plays crucial roles in both cell death signaling pathways and DNA repair, respectively. Oxidative stress induced by aggregated beta-amyloid $(\mathrm{A} \beta)$ peptide, altered DNA repair and transcriptional activation of cell death pathways have been implicated in the pathophysiology of Alzheimer's disease (AD). Here we show that varying concentrations of $A \beta_{1-42}$ differentially regulate Ref-1 expression, Ref-1 function and neuronal survival in vitro. A $\beta(5.0 \mu \mathrm{M})$ caused a relatively rapid decrease in Ref-1 expression and activity associated with extensive DNA damage and neuronal degeneration. In contrast, Ref-1 induction occurred in cells exposed to $\mathrm{A} \beta(1.0 \mu \mathrm{M})$ without significant neuronal cell death. $\mathrm{A} \beta$-induced attenuation of Ref- 1 expression and endonuclease activity, and neuronal cell death were prevented by the anti-oxidant, catalase. Similar differential effects on Ref-1 expression and cell viability were observed in N2A neuroblastoma cells treated with either high or low dose hydrogen peroxide. These findings demonstrate the differential regulation of Ref- 1 expression by varying degrees of oxidative stress. Parallels between the Ref- 1 response to $A \beta$ and $\mathrm{H}_{2} \mathrm{O}_{2}$ suggest similarities between DNA repair pathways activated by different inducers of oxidative stress. In AD brain, colocalization of Ref- 1 and $A \beta$ the absence of significant DNA damage are consistent with the cell culture results and suggests that Ref- 1 may play a more neuroprotective role under these conditions. Modulation of Ref- 1 expression and activity by local variations in A $\beta$ concentration may be an important determinant of neuronal vulnerability to oxidative stress in AD.
\end{abstract}

\section{INTRODUCTION}

Increasing evidence indicates that cellular reductionoxidation (redox) status regulates a variety of key intracellular processes including gene expression, cell proliferation and cell death [1-3]. Redox factor-1 (Ref-1), also known as APE-1 or APEX or HAP1, is a $37 \mathrm{kDa}$ nuclear protein that participates in the redox regulation of gene transcription as well as the cellular response to oxidative stress [3, 4]. Through cleavage of abasic (apurinic/apyrimidinic) sites by its endonuclease (APE) activity, Ref-1/APE-1 plays a major role in the repair of DNA stand breaks induced by endogenously generated reactive oxygen species (ROS) and exogenous agents such as ionizing radiation and chemotherapeutic drugs [5-7]. In addition, Ref- 1 modulates the redox state of conserved cysteine residues within the DNA-binding domain of transcription factors such as AP-1, NF-kappaB and p53, resulting in transcriptional activation of downstream genes such as nitric oxide synthase [8, 9].

\footnotetext{
*Address correspondence to this author at the Department of Neurology, University of California Irvine School of Medicine, 100 Irvine Hall, ZOT 4275, Irvine, CA 92697-4275, USA; Tel: 949-824-1669; Fax: 949-8243135; E-mail: tanz@uci.edu

${ }^{\S}$ These authors contributed equally to this work.

${ }^{\dagger}$ Current address: Department of Internal Medicine, University of Iowa Roy J. and Lucille A. Carver College of Medicine, and Veterans Administration Medical Center, Iowa City, Iowa.
}

Currently the dual functions of Ref-1, i.e., DNA repair versus transcriptional regulation, relevant to the central nervous system (CNS) response to injury are poorly understood. Ref-1 is highly expressed in proliferating cells during embryonic and early postnatal development [10, 11]. In contrast, relatively lower amounts of Ref-1 are found in the adult CNS, particularly in astrocytes, neurons in hippocampus and piriform cortex, as well as cerebellar Purkinje cells [12]. Attenuation or loss of Ref-1 activity has been associated with marked sensitivity to DNA-damaging agents and increased cell death [7, 13, 14]. Downregulation of Ref-1 expression has also been reported in vulnerable neurons following cerebral ischemia [15-17]. However, increased Ref-1 expression has been demonstrated in both surviving and vulnerable neurons following an ischemic or excitotoxic insult in rat brain [18, 19]. In Alzheimer's disease (AD) brain, Ref-1 protein was found to accumulate in vulnerable neurons as well as senile plaques [20]. As $\beta$-amyloid (A $\beta)$ induced oxidative stress, altered DNA repair and activation of transcription factors such as AP-1 and p53 have been implicated in the pathophysiology of AD [21-24], a role for Ref- 1 as a mediator of $A \beta$-induced neurodegeneration seems plausible.

The present study was conducted to determine the effects of different concentrations of $A \beta$ and oxidative stress on Ref-1 expression and neuronal survival, and to examine the potential relationship between Ref- 1 induction, $A \beta$ accumulation and neurodegeneration in AD. The results strengthen the idea that Ref-1 induction is neuroprotective while loss of 
Ref-1 may lead to neurodegeneration. Differential modulation of Ref-1 expression by local variations in the concentration of $\beta$-amyloid may contribute to selective neuronal vulnerability in AD.

\section{MATERIALS AND METHODOLOGY}

$\beta$-amyloid $\left(\mathrm{A} \beta_{1-42}\right)$ peptide was purchased from U.S. Peptide (Fullerton, CA, USA). Neurobasal medium and B27 supplement were purchased from Invitrogen (Carlsbad, CA). In Situ Cell Death Detection and Cytotoxicity Detection Kits were purchased from Roche Diagnostics (Indianapolis, IN). Rabbit anti-Ref-1 and anti-A $\beta_{1-42}$ polyclonal antibodies were purchased from Santa Cruz Biotechnology (Santa Cruz, CA) and Quality Controlled Biochemicals (QCB, Hopkinton, MA), respectively. Mouse anti-Ref-1 monoclonal antibody was purchased from BD PharMingen (San Diego, CA). Fluorescein isothiocyanate (FITC)-conjugated goat anti-rabbit IgG and catalase were purchased from Sigma (St. Louis, MO). Texas Red-or rhodamine-conjugated goat anti-mouse IgG was purchased from Chemicon (Temecula, CA). Biotinylated goat anti-rabbit IgG, ABC and diaminobenzidine (DAB) staining kits were purchased from Vector Laboratories (Burlingame, CA).

Timed pregnant Sprague-Dawley rats were purchased from Charles River Laboratories (Wilmington, MA). Human postmortem brain samples (12 subjects with a histopathological diagnosis of $\mathrm{AD}$ and 9 age-matched controls) were obtained from the Alzheimer's Disease Research Consortium at the University of Southern California and the Institute for Brain Aging and Dementia Tissue Repository at the University of California Irvine. The average age of each group was 81.0 and 79.5 years for the AD cases and controls, respectively.

All procedures were approved by both University of Southern California Keck School of Medicine and University of California Irvine School of Medicine Institutional Review Boards and Animal Utilization and Care Committees. Rats were treated in accordance with the NIH Guide for the Care and Use of Laboratory Animals.

\section{Cell Culture}

Neuron cultures were prepared from the hippocampus of Sprague-Dawley rats at 18 days of gestation (E18) as previously described $[25,26]$. Briefly, hippocampi were dissected in $\mathrm{Ca}^{2+} / \mathrm{Mg}^{2+}$-free Hank's balanced salt solution (HBSS) under a stereomicroscope and incubated in $0.1 \%$ trypsin (Irvine Scientific) at $37{ }^{\circ} \mathrm{C}$ for $5 \mathrm{~min}$. The tissue was triturated by aspirating 7 to 10 times with a flame-narrowed Pasteur pipette. Cells were plated onto poly-D-lysine-coated $60 \mathrm{~mm}$ tissue culture dishes, 8-well chamber slides or 96-well microplates at approximately $10^{4}$ cells per $\mathrm{cm}^{2}$ in serum-free Neurobasal medium plus B27 supplement for optimum survival of CNS neurons. The medium was exchanged with fresh medium 3 days after initial plating. All cultures were grown in a humidified atmosphere containing $5 \% \mathrm{CO}_{2}$ at $37^{\circ} \mathrm{C}$.

\section{Preparation and Exposure of Aggregated $\beta$-Amyloid Peptide}

$\mathrm{A} \beta_{1-42}$ peptide was initially dissolved in $10 \mathrm{mM} \mathrm{HCl}$ and then preaggregated in $0.1 \mathrm{M}$ phosphate buffer $(\mathrm{pH}$ 7.2) for 3 days prior to use. Aggregation was confirmed by visualization of $\beta$-amyloid fibrils using phase contrast microscopy. Seven days after initial plating the culture medium was changed to medium supplemented with either aggregated $\mathrm{A} \beta_{1-42}$ peptide or vehicle. At the specified times cells were either fixed with $4 \%$ paraformaldehyde in 1xphosphate buffer (PBS) for immunocytochemistry or harvested for biochemical analysis.

\section{Immunostaining}

For immunocytochemistry, fixed cells were incubated with a rabbit anti-human Ref-1 polyclonal antibody (1:200, Santa Cruz Biotechnology, Santa Cruz, CA) for $2 \mathrm{hr}$ at room temperature, followed by a biotinylated secondary antibody for $30 \mathrm{~min}$ and $0.6 \% \mathrm{H}_{2} \mathrm{O}_{2} / 2 \%$ Triton $\mathrm{X}-100$ in $1 \mathrm{X}$ PBS for $10 \mathrm{~min}$. Immunoreactivity was detected using the $\mathrm{ABC}$ method (Vector Laboratories, Burlingame, CA) followed by staining with diaminobenzidine (DAB) (Vector Laboratories).

For the AD studies, tissue blocks containing hippocampus plus surrounding temporal cortex were fixed in $10 \%$ neutral-buffered formalin, paraffin-embedded and sectioned at $6 \mu \mathrm{m}$. Deparaffinized sections were-rehydrated prior to microwave antigen retrievial. Sections were then incubated with the following combinations of antibodies: mouse antiRef-1 (1:100, Chemicon) plus rabbit anti-A $\beta_{1-42}(1: 100$, QCB), or rabbit anti-Ref-1 and either mouse anti-GFAP (1:200, Roche) or anti-NeuN (1:200, Chemicon) overnight at $4{ }^{\circ} \mathrm{C}$. This was followed by incubation with FITCconjugated sheep anti-rabbit (1:200, Sigma) and Texas Redconjugated goat anti-mouse (1:80, Chemicon) secondary antibodies for $30 \mathrm{~min}$. To block endogenous lipofucsin autofluorescence sections were stained with $0.5 \%$ Sudan black B in ethanol for $10 \mathrm{~min}$ followed by several PBS washes [27]. For dual labeling of DNA damage and Ref-1, sections were re-microwaved after TUNEL staining (see below), incubated in blocking buffer for $30 \mathrm{~min}$ at room temperature, washed in PBS and incubated with Ref- 1 antibody followed by a biotinylated secondary antibody. After several PBS washes Ref-1 immunoreactivity was detected using streptavidinconjugated Texas Red (Amersham, Piscataway, NJ).

\section{Evaluation of Neuronal Damage}

TdT-mediated dUTP nick end labeling (TUNEL) was employed to detect neuronal DNA damage in both cultured cells and human brain sections. Brain sections were fixed and microwaved as described above, labeled with an In Situ Cell Death Detection (fluorescein) kit (Roche, Indianapolis, IN) according to the manufacturer's protocol, and analyzed by fluorescence microscopy. For combined labeling of TUNEL and Ref-1, slides were then incubated with mouse anti-Ref-1 monoclonal IgG (1:200, BD PharMingen) followed by incubation with a rhodamine-conjugated goat anti-mouse IgG (Chemicon) and visualized by fluorescence microscopy. For N2A cells, TUNEL was performed using an In Situ Cell Death Detection (POD) kit followed by (aminoethylcarbazole) AEC chromogenic visualization. Cell death in vitro was also assayed by lactate dehydrogenase (LDH) release using a Cytotoxicity Detection Kit (Roche) following manufacturer's manual. 

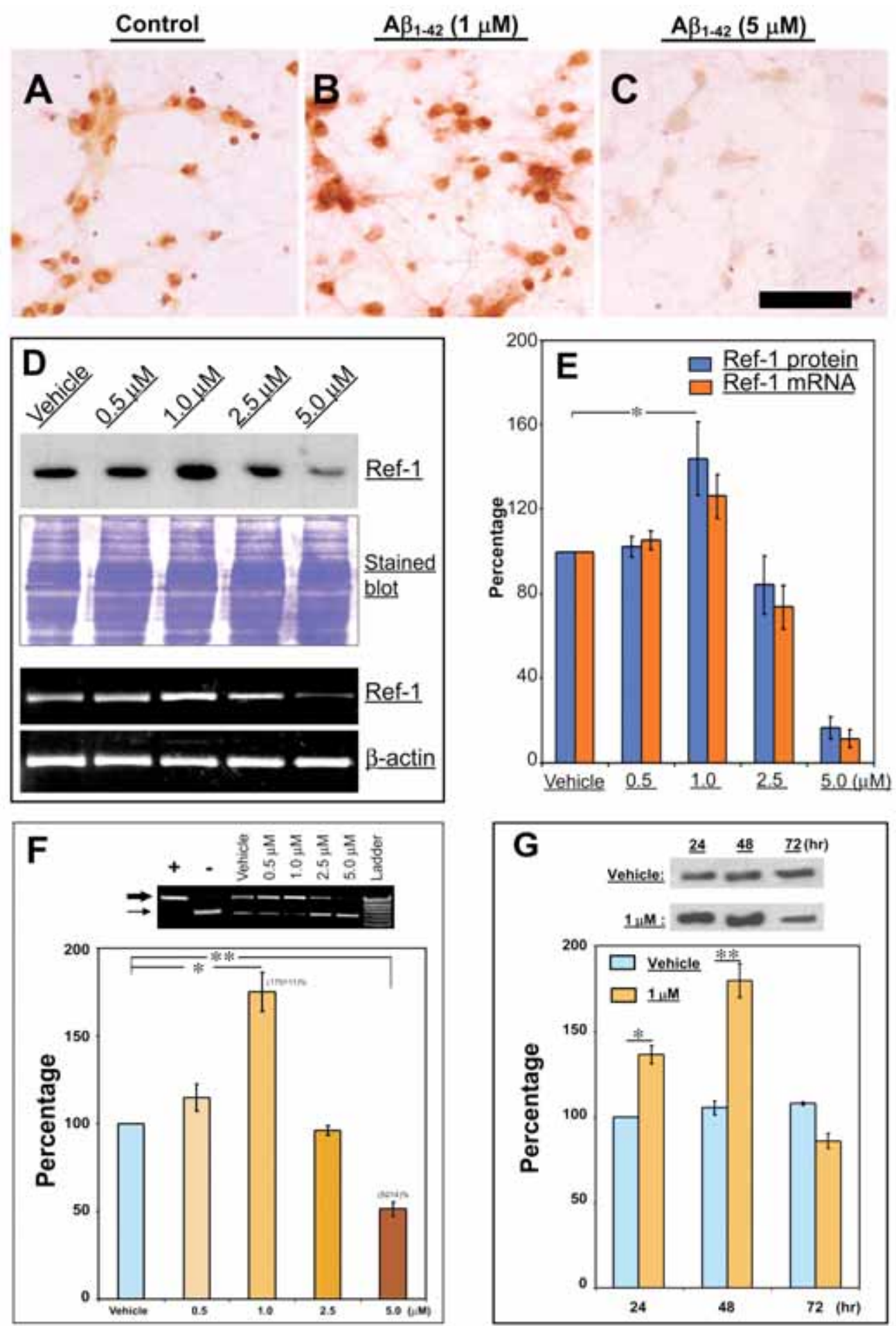

Fig. (1). Differential expression and APE activity of Ref-1 following A $\beta$ treatment in primary neurons. (A-C) Immunohistochemistry using Ref-1 specific antibody reveals nuclear-predominant staining in vehicle control (A), increased staining after incubation with $1.0 \mu \mathrm{M} A \beta_{1-42}$ for $24 \mathrm{hr}(\mathbf{B})$, and decreased staining after incubation with $5.0 \mu \mathrm{M} \mathrm{A} \beta_{1-42}$ for $3 \mathrm{hr}(\mathbf{C})$. (D) Western blotting (1 st panel) and RT-PCR (3 ${ }^{\text {rd }}$ and $4^{\text {th }}$ panels) confirms changes in abundance of both Ref-1 protein in cell lysates and Ref- 1 mRNA ( $3^{\text {rd }}$ panel) 6 hr following $5.0 \mu \mathrm{M} \mathrm{A} \beta_{1-42}$ and $24 \mathrm{hr}$ following the other treatments. Coomassie blue stained blot $\left(2^{\text {nd }}\right.$ panel) shows equal loading amount of lysates in each lane. $\beta$-actin was used as cDNA loading control. (E) The relative changes in abundance of Ref-1 protein and mRNA are quantified and depicted relative to the controls. The quantitative results are depicted relative to the control. (F) APE activity assay reveals differential changes in Ref-1 endonuclease activity in neurons after treatment. Closed form of depurinated DNA (thin arrow) moved to the top (bold arrow) after cleavage mediated by Ref-1 APE activity. +, with saturated control lysates; -, with heat-deactivated control lysates; The results were quantified by optical densitometry and are depicted relative to the controls. (G) Western blotting shows changes of Ref-1 protein in neurons with time following treatment with $1 \mu \mathrm{M} \mathrm{A} \beta_{1-42}$. The quantitative results are depicted relative to the vehicle control. Bars represent the mean \pm SE from four independent experiments ( $\mathrm{p}^{*}<0.05$; $* *<0.01$, as per Student $t$-test). Scale bar $=50 \mu \mathrm{m}$. 


\section{Reverse Transcription-Polymerase Chain Reaction (RT-PCR)}

Total RNA was extracted from cultured cells using TRIzol (Invitrogen) and reverse transcribed using $1 \mu \mathrm{g}$ oligo(dT) in $20 \mu \mathrm{l}$ of reaction buffer $(1 \mathrm{mM}$ each dNTPs, $25 \mathrm{mM}$ Tris$\mathrm{Cl}$ (pH 8.3), $25 \mathrm{mM} \mathrm{KCl}, 5 \mathrm{mM} \mathrm{MgCl} 2,5 \mathrm{mM}$ dithiothreitol, $0.25 \mathrm{mM}$ spermidine, $10 \mathrm{u}$ RNase inhibitor (Roche, Indianapolis, IN), $10 \mathrm{u}$ avian myeloblastosis virus reverse transcriptase (Promega) incubated for $1 \mathrm{hr}$ at $42{ }^{\circ} \mathrm{C}$ and $40 \mathrm{~min}$ at $52{ }^{\circ} \mathrm{C}$. The reaction was stopped by adding $160 \mu \mathrm{l}$ of $10 \mathrm{mM}$ Tris- $\mathrm{HCl}(\mathrm{pH} 7.4)$ and $1 \mathrm{mM}$ EDTA. PCR was performed with $10 \mu \mathrm{l}$ of RT reaction mixture, $50 \mathrm{mM} \mathrm{KCl}, 10 \mathrm{mM}$ Tris$\mathrm{Cl}$ (pH 9.0), $0.1 \%$ Triton X-100, $1 \mathrm{mM} \mathrm{MgCl}, 400 \mathrm{nM}$ each primer, $200 \mu \mathrm{M}$ each dNTP, 5 u Taq DNA polymerase (Boehringer) in a final volume of $50 \mu \mathrm{l}$. Ref-1 primers: (forward) 5'-AATGTGGATGGGCTTCGA-3'; (reverse) 5'-GCGCCAACCAACATTCTT-3' (Integrated DNA Technologies, Coralville, IA). Samples were subjected to $30 \mathrm{cy}-$ cles $\left(94{ }^{\circ} \mathrm{C}, 1 \mathrm{~min} ; 58{ }^{\circ} \mathrm{C}, 1 \mathrm{~min} ; 72{ }^{\circ} \mathrm{C}, 3 \mathrm{~min}\right)$ in a DNA Thermal Cycler (Perkin Elmer, Norwalk, CT), and $5 \mu 1$ of the PCR products were analyzed by electrophoresis on a $1 \%$ agarose gel. For semi-quantitative PCR, amplification of $\beta$-actin was used as a control for densitometric analysis.

\section{AP Endonuclease Activity Assay}

AP endonuclease activity was assayed as previously described [28] with certain modification. Briefly, harvested cells were re-suspended and sonicated in AP lysis buffer (70 mM HEPES pH 7.6, $400 \mathrm{mM} \mathrm{NaCl}, 1 \mathrm{mM}$ EDTA, $1 \mathrm{mM}$ DTT, $10 \%$ glycerol, $0.2 \%$ Triton X-100). Total protein concentrations of the supernatants were determined by a Sigma Total Protein Assay kit. To assay AP activity of prepared lysates, QIAGEN column-purified pDsRed1-C3 $(4.7 \mathrm{~kb})$ (Clontech) plasmid DNA was depurinated by heating in $10 \mathrm{mM}$ sodium citrate, $0.1 \mathrm{M} \mathrm{NaCl} \mathrm{pH5} .2$ at $70{ }^{\circ} \mathrm{C}$ for $45 \mathrm{~min}$. APE reaction consisted of $20 \mathrm{ng}$ (total protein) of cell extract, $300 \mathrm{ng}$ of undamaged (control) or depurinated pDsRed1-C3 plasmid (Clontech) in $40 \mathrm{mM}$ HEPES, $5 \mathrm{mM}$ $\mathrm{MgCl}_{2}, 0.5 \mathrm{mM}$ DTT, $2 \mathrm{mM}$ ATP, $75 \mathrm{mM} \mathrm{NaCl}, 0.36 \mathrm{mg} / \mathrm{ml}$ bovine serum albumine $\mathrm{pH} 7.8$ at $30{ }^{\circ} \mathrm{C}$ for $10 \mathrm{~min}$ in a total volume of $50 \mu \mathrm{l}$. The reaction was stopped by addition of EDTA to $20 \mathrm{mM}$ final concentration and by freezing on dry ice. Nicked (APE-cleaved) and closed supercoiled forms of plasmids were resolved by $1.0 \%$ agarose gel electrophoresis in the presence of ethidium bromide.

\section{Western Blot}

After treatment cultured cells were rinsed and harvested in buffer containing $20 \mathrm{mM}$ Tris- $\mathrm{HCl}(\mathrm{pH} 7.4), 0.15 \mathrm{M}$ $\mathrm{NaCl}, 1 \mathrm{mM}$ EDTA, $1 \mathrm{mM}$ EGTA, $1.2 \%$ triton X-100, $1 \mathrm{mM}$ $\mathrm{Na}_{3} \mathrm{VO}_{4}, 100 \mu \mathrm{g} / \mathrm{ml}$ phenylmethylsulfonyl fluoride, $2 \mu \mathrm{g} / \mathrm{ml}$ leupeptin, $5 \mu \mathrm{g} / \mathrm{ml}$ aprotinin. Cell lysates were rotated for 1 hr at $4{ }^{\circ} \mathrm{C}$, centrifuged at $10,000 \mathrm{Xg}$ for $10 \mathrm{~min}$ and $50 \mu \mathrm{g}$ of protein per lane was resolved by sodium dodecyl sulfatepolyacrylamide gel electrophoresis. Gels were transferred to a nitrocellulose membrane (Millipore, Bedford, MA) in a Hoefer Transphor Electrophoresis Unit. Following blocking with $10 \mathrm{mM}$ Tris- $\mathrm{HCl}$ (pH 7.5), $0.15 \mathrm{M} \mathrm{NaCl}, 0.01 \%$ Tween-20 and 5\% nonfat dry milk, membranes were incubated for $2 \mathrm{hr}$ with anti-Ref-1 antibody (1:500 dilution, Santa Cruz) and anti-rabbit HRP secondary antibody for $1 \mathrm{hr}$.
Proteins were detected by enhanced chemiluminescence and exposure to hyperfilm (Amersham). Protein assays were performed using a Total Protein Assay Kit (Sigma).

\section{RESULTS}

\section{Effects of $A \beta$ on Expression and Activity of Ref-1 Protein in Neurons}

Previous studies demonstrated dose-dependent neurotoxic effects of $A \beta$ peptides in vitro $[29,30]$. High concentrations of pre-aggregated $A \beta_{1-42}(>5.0 \mu \mathrm{M})$ directly cause acute neuronal cell death in cultures, whereas the lower concentrations of $\mathrm{A} \beta(0.1 \sim 1 \mu \mathrm{M})$ might sensitize neuronal cells to make them more vulnerable to further stress without causing immediate neuronal degeneration [30]. To examine whether low and high concentrations of $A \beta_{1-42}$ have differential effects on Ref-1 expression, primary hippocampal neurons maintained in culture for 5-7 days were incubated in medium containing pre-aggregated $A \beta_{1-42}$ at a concentration of either $1.0 \mu \mathrm{M}$ or $5.0 \mu \mathrm{M}$. In vehicle-treated cells there was a moderate amount of Ref-1 immunoreactivity that was predominantly nuclear (Fig. 1A). Incubation with lower concentrations $(0.5 \sim 1.0 \mu \mathrm{M})$ of $\mathrm{A} \beta_{1-42}$ caused an increase in Ref-1 expression (Figs. 1D \& E) that was maintained for up to 48 $\mathrm{hr}$ as confirmed by Western blotting (Fig. 1G). However, persistent exposure to $1.0 \mu \mathrm{M} \mathrm{A} \beta_{1-42}$ for more than $72 \mathrm{hrs}$ was associated with a decline in Ref-1 expression (Fig. 1G). In contrast, there was a marked decrease in Ref- 1 expression, by $6 \mathrm{hr}$ following exposure to $5 \mu \mathrm{M} \mathrm{A} \beta_{1-42}$ (Fig. 1C). These findings were corroborated by Western blot analysis of Ref- 1 expression along with similar changes from RT-PCR analysis of Ref-1 mRNA (Figs. 1D \& E). Additionally, an apurinic/apyrimidinic endonuclease (APE) activity assay was performed to measure the major DNA repair function of Ref-1. The results demonstrated changes that paralleled those of Ref-1 protein (Fig. 1F).

\section{Effects of $A \beta$ Concentration on Neuronal Survival}

Decreased Ref-1 abundance has been linked with increased neuronal cell death both in vivo and in vitro $[14,15]$. As Ref- 1 expression varied with the concentration of $A \beta$, the differential effects of low versus high dose $A \beta$ on neuronal survival were evaluated in cultured neurons by phase contrast microscopy, TUNEL staining and lactose dehydrogenase (LDH) release assay. In vehicle-treated control cultures as well as cultures receiving a relatively low dose of $\mathrm{A} \beta(1.0 \mu \mathrm{M})$, cellular morphology appeared normal (Figs. $\mathbf{2 A} \& \mathbf{B})$. In contrast, exposure to $\mathrm{A} \beta(5.0 \mu \mathrm{M})$ resulted in the rapid appearance of morphological and biochemical evidence of cell death, i.e., positive TUNEL staining and increased LDH release (Figs. 2C-H). Importantly, persistent exposure to $\mathrm{A} \beta(1.0 \mu \mathrm{M})$ for more than $72 \mathrm{hrs}$ was associated with biochemical evidence of neuronal degeneration (Fig. 2H).

\section{Relationship between Ref-1 and $A \beta$ in Alzheimer's Dis-} ease

As Ref- 1 is regulated by $A \beta$ in a concentration-dependent manner in vitro, the accumulation of Ref-1 in AD [20] suggested that there may be a relationship between Ref-1 and $\mathrm{A} \beta$ in AD. Double-labeling of Ref- 1 and either a neuronal $(\mathrm{NeuN})$ or astrocytic (glial fibrillary acidic protein) marker 

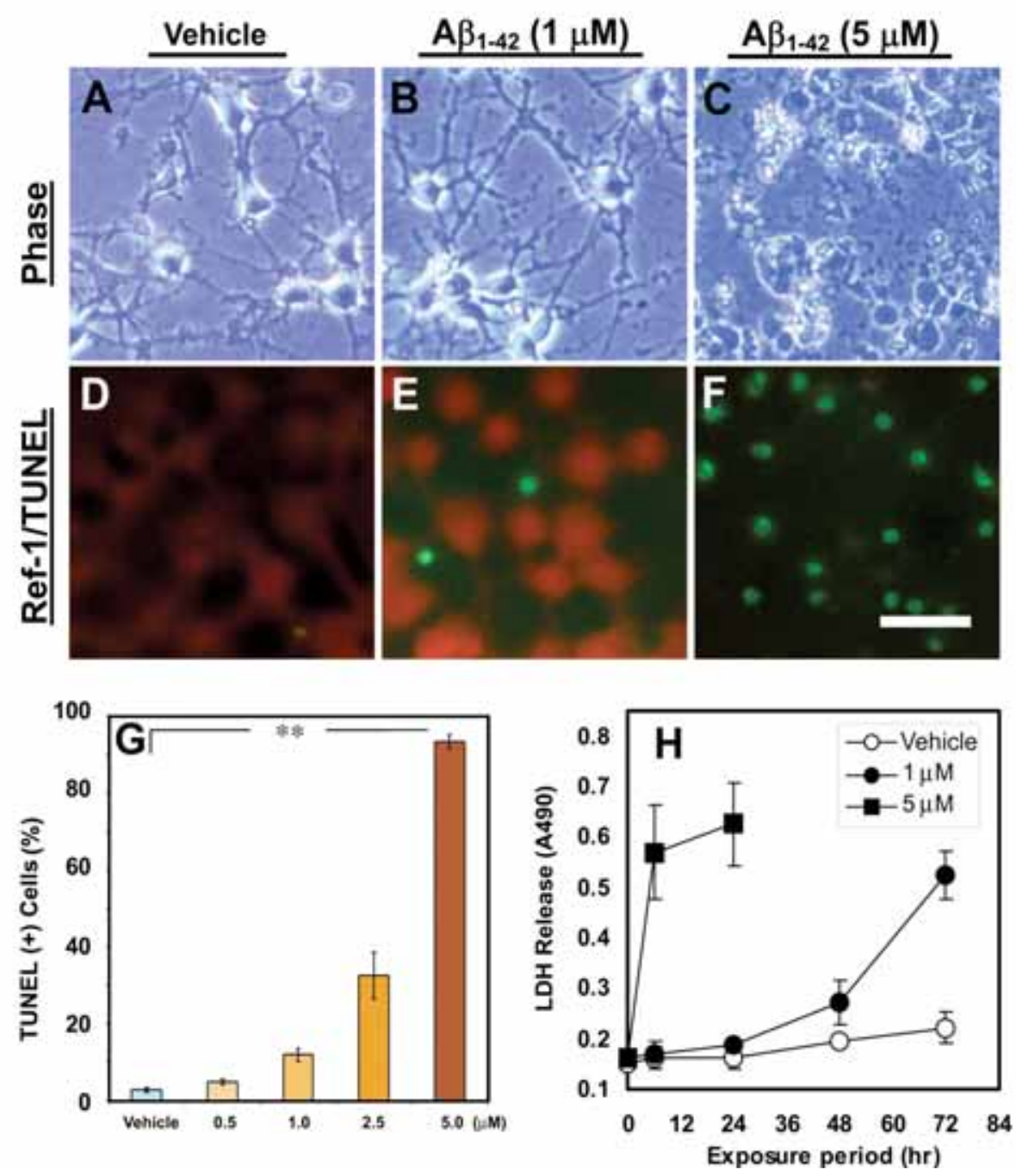

Fig. (2). Reciprocal relationship between Ref-1 and neuronal cell death due to A $\beta$ treatment. (A-C) Phase contrast microscopy shows normal or relatively normal morphology in vehicle-treated or low dose $A \beta_{1-42}$-treated neurons at $24 \mathrm{hr}$ (A \& B). After 3 hr incubation with high dose $\mathrm{A} \beta_{1-42}$ there is extensive cell body disruption and retraction of processes consistent with cell death (C). (D-F) TUNEL-Ref-1 double labeling demonstrates few TUNEL-positive cells (green) $24 \mathrm{hr}$ after $1.0 \mu \mathrm{M} \mathrm{A} \beta_{1-42}(\mathbf{E})$ and a significantly higher number of TUNEL-positive cells after $5.0 \mu \mathrm{M} \mathrm{A} \beta_{1-42}(\mathbf{F})$. (G) Neurons were assayed by TUNEL $3 \mathrm{hr}$ after $5.0 \mu \mathrm{M} \mathrm{A} \beta_{1-42}$ or $24 \mathrm{hr}$ following the other treatments as indicated. Quantitative results demonstrate the increase in TUNEL-positive cells by $3 \mathrm{hr}$ after $5.0 \mu \mathrm{M}$ or $24 \mathrm{hr}$ after $2.5 \mu \mathrm{M}$ A $\beta_{1-42}$ treatment. (H) LDH release demonstrates a relatively rapid progression to cell death following $5.0 \mu \mathrm{M} \mathrm{A} \beta_{1-42}$ treatment. Bars represent the mean $\pm \mathrm{SE}(* * \mathrm{p}<0.01$, $\mathrm{N}=4$, as per Student $t$-test). Scale bar $=30 \mu \mathrm{m}$.

demonstrated that Ref-1-immunoreactive cells were predominantly neurons. In addition, Ref-1 immunoreactivity colocalized with intracellular A $\beta$ (Figs. 3G-I), and both diffuse and dense-core senile plaques (Figs. 3J-O). Dual staining of Ref-1 and TUNEL demonstrated that a small number of Ref-1-immunoreactive cells in the AD hippocampus were TUNEL-positive (Figs. 3P-R). Conversely, the majority of Ref-1-positive cells in the AD hippocampus and all of the Ref-1-positive cells in control brains were TUNELnegative (Figs. 3P-U).

\section{Differential Regulation of Ref-1 Expression and Modula- tion of Neuronal Survival by Oxidative Stress}

A $\beta$-induced production of hydrogen peroxide $\left(\mathrm{H}_{2} \mathrm{O}_{2}\right)$, may contribute to neurodegeneration in $\mathrm{AD}[29,31]$. We therefore sought to determine the effects of $\mathrm{H}_{2} \mathrm{O}_{2}$ on Ref-1 expression. N2A neuroblastoma cells, which express a rela- tively high basal level of Ref-1, were treated with $\mathrm{H}_{2} \mathrm{O}_{2}$ $(0.1 \mathrm{mM} \sim 10 \mathrm{mM})$ and both Ref- 1 expression and cell death were evaluated by Western blotting and TUNEL, respectively. Several hours following treatment with $10 \mathrm{mM} \mathrm{H}_{2} \mathrm{O}_{2}$ a striking downregulation of Ref- 1 expression and activity occurred (Fig. 4D) in association with increased cell death (Fig. 4C). In contrast, cells treated with $0.1 \mathrm{mM} \mathrm{H}_{2} \mathrm{O}_{2}$ exhibited a transient increase in Ref- 1 expression (Fig. 4E) without any significant morphological changes (Figs. 4A, B). To further explore the connection between $\mathrm{A} \beta, \mathrm{H}_{2} \mathrm{O}_{2}$ and Ref-1, $\mathrm{A} \beta$-treated neurons were incubated with catalase (CAT), which catalyzes the breakdown of $\mathrm{H}_{2} \mathrm{O}_{2}$. Co-treatment with CAT significantly prevented $\mathrm{A} \beta$-induced downregulation of Ref- 1 protein and loss of APE activity (Fig. 4I). In contrast there were no significant changes in either Ref-1 expression or activity in control cells after CAT treatment (data not shown). In association with the preservation of Ref-1 

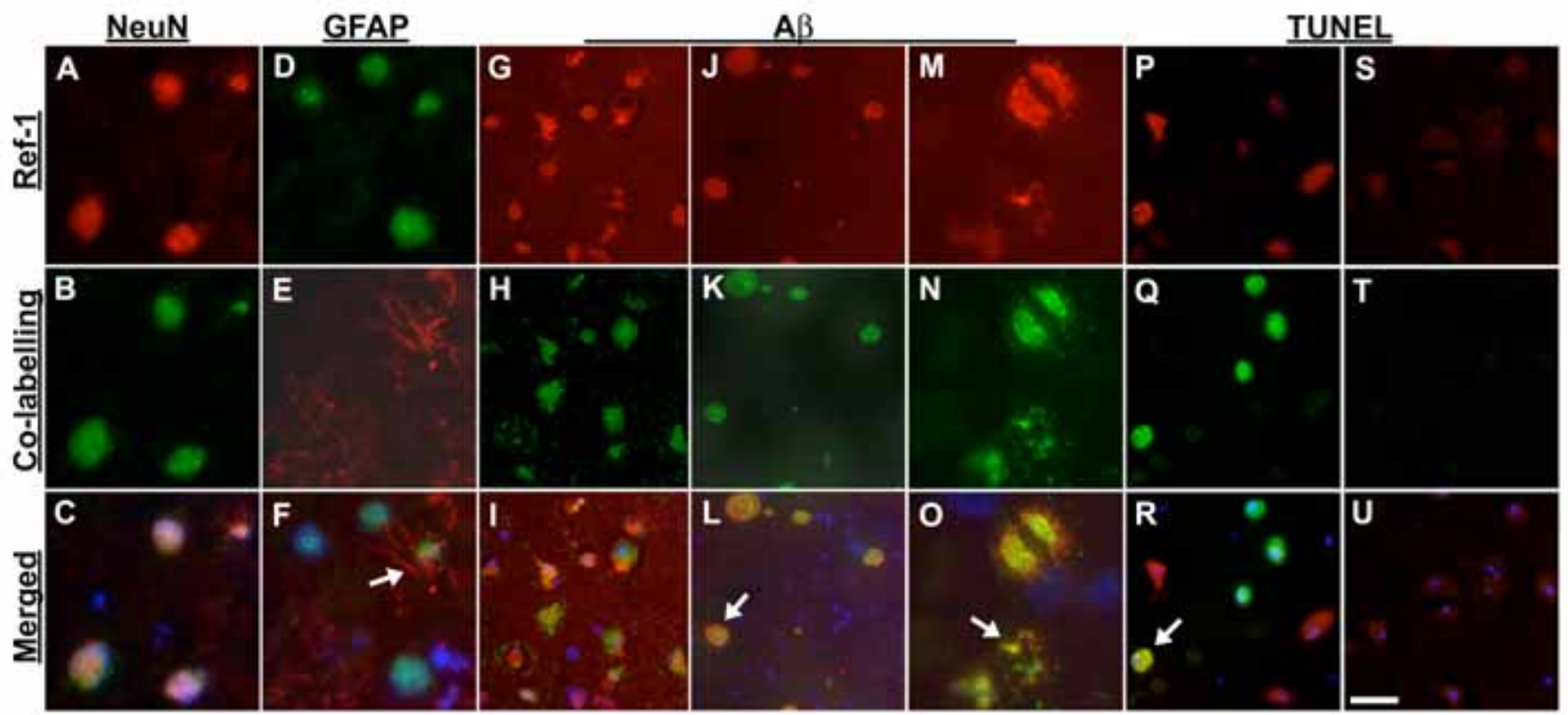

Fig. (3). Pattern of Ref-1 expression in the AD brain. Brain sections were dual stained for Ref- 1 and other markers as indicated at the top of the figure. (A-F) Ref-1 immunoreactivity (A,D) and co-labeling with either (B) a neuronal marker, NeuN, or (E) an astrocytic marker, glial fibrillary acidic protein (GFAP), reveals that most Ref-1-positive cells in the AD hippocampus are neurons (C). Arrow in (F) shows a Ref-1positive astrocyte. Cells were counterstained with DAPI which appears blue (C,F). (G-O) Dual staining demonstrates colocalization of Ref-1 $(\mathrm{G}, \mathrm{J}, \mathrm{M})$ and $\mathrm{A} \beta(\mathrm{H}, \mathrm{K}, \mathrm{N})$ in cells (I, merged images) and both condensed and diffuse senile plaques (arrows in merged images $\mathbf{L}$ and $\mathbf{O}$, respectively). (P-R) Most of the cells that express Ref-1 (P) do not exhibit DNA damage by TUNEL (Q) as shown in the merged images (R). A small number of Ref-1-positive cells are also TUNEL-positive (R, arrow). (S-U) Ref-1 immunoreactive (S) but TUNEL-negative (T) cells are present in an age-matched control brain. DAPI (blue) counterstaining confirms the presence of cell nuclei (U). Scale bar represents $20 \mu \mathrm{m}$ in $\mathrm{A}-\mathrm{F} \& \mathrm{M}-\mathrm{O}$, and $80 \mu \mathrm{m}$ in other panels.

expression and activity, CAT efficiently protected against $\mathrm{A} \beta$-induced neuronal cell death as demonstrated by cell morphology (Figs. 4F-H).

\section{DISCUSSION}

The importance of Ref-1 during the response to oxidative stress has previously been demonstrated in non-neural cells $[5,7,32]$. Ref-1 expression is induced within several hours of exposure to ROS-generating agents [5, 7]. In contrast, Ref-1 depletion increases vulnerability to DNA-damaging agents as well as hypoxia and hyperoxia [7]. Among its major functions Ref-1 protein is an endonuclease that participates in the base excision repair of DNA strand breaks induced by $\operatorname{ROS}[6,33]$. We surmised that Ref- 1 might play an important role in the CNS response to ROS-generating agents such as $\mathrm{H}_{2} \mathrm{O}_{2}$ and $\mathrm{A} \beta$. Accordingly, we found that Ref- 1 expression and activity are differentially regulated by exposure to varying concentrations of ROS generators. The results imply an indirect relationship between the level of Ref-1 expression/activity and neuronal damage. Specifically, high concentrations of ROS-generators may impair Ref-1mediated DNA repair as evidenced by downregulation of Ref-1 expression and widespread DNA damage. In contrast, exposure to lower concentrations of ROS-generators induce moderate DNA damage and activation of the Ref-1 pathway. In addition to functioning in DNA damage repair, Ref-1 protein may activate $\mathrm{p} 53, \mathrm{NFkB}$ and other transcription factors that regulate cell death [4, 9]. Increased Ref-1 expression might simultaneously activate the transcriptional activity of p53, a tumor suppressor that plays important roles in apopto- sis and neuronal degeneration [34, 35], resulting in delayed cell death. This is supported by our finding that massive cell death eventually occurred despite an induction of Ref-1 protein in cells exposed to low toxin concentrations. Taken together, our results suggest that upregulation of Ref-1 by mild to moderate degrees of oxidative damage may facilitate transient cell survival through its DNA repair function, while severe oxidative damage may lead to decreased Ref-1 production which promotes rapid cell death. This hypothesis is supported by varying levels of Ref-1 expression in association with either neuronal survival or degeneration following transient cerebral ischemia [15-18]. Additionally, a direct causal relationship between Ref- 1 induction and neuronal survival was recently demonstrated in vitro [14].

Accumulating evidence has implicated ROS in the pathophysiology of AD and other neurodegenerative diseases [24, 36, 37]. Oxidative damage has been reported in transgenic mouse models as well as human AD [23, 38-40], while other reports have demonstrated increased ROS production in neurons exposed to either $\mathrm{H}_{2} \mathrm{O}_{2}$ or $\mathrm{A} \beta$ [41, 42]. Thus, $A \beta$-mediated generation of $\mathrm{H}_{2} \mathrm{O}_{2}$ and ROS may contribute to oxidative damage and neuronal loss in AD. In this regard, prior reports of DNA damage, abnormal DNA repair and neuronal apoptosis [23, 43, 44] suggest that Ref-1 may regulate the cellular response to ROS in AD. Our finding that CAT blocked $A \beta$-induced downregulation of Ref-1 protein strengthens this notion. We previously found that Ref- 1 accumulates in vulnerable neurons and senile plaques in the AD brain [20]. The present study corroborates and extends these observations by demonstrating both neuronal 

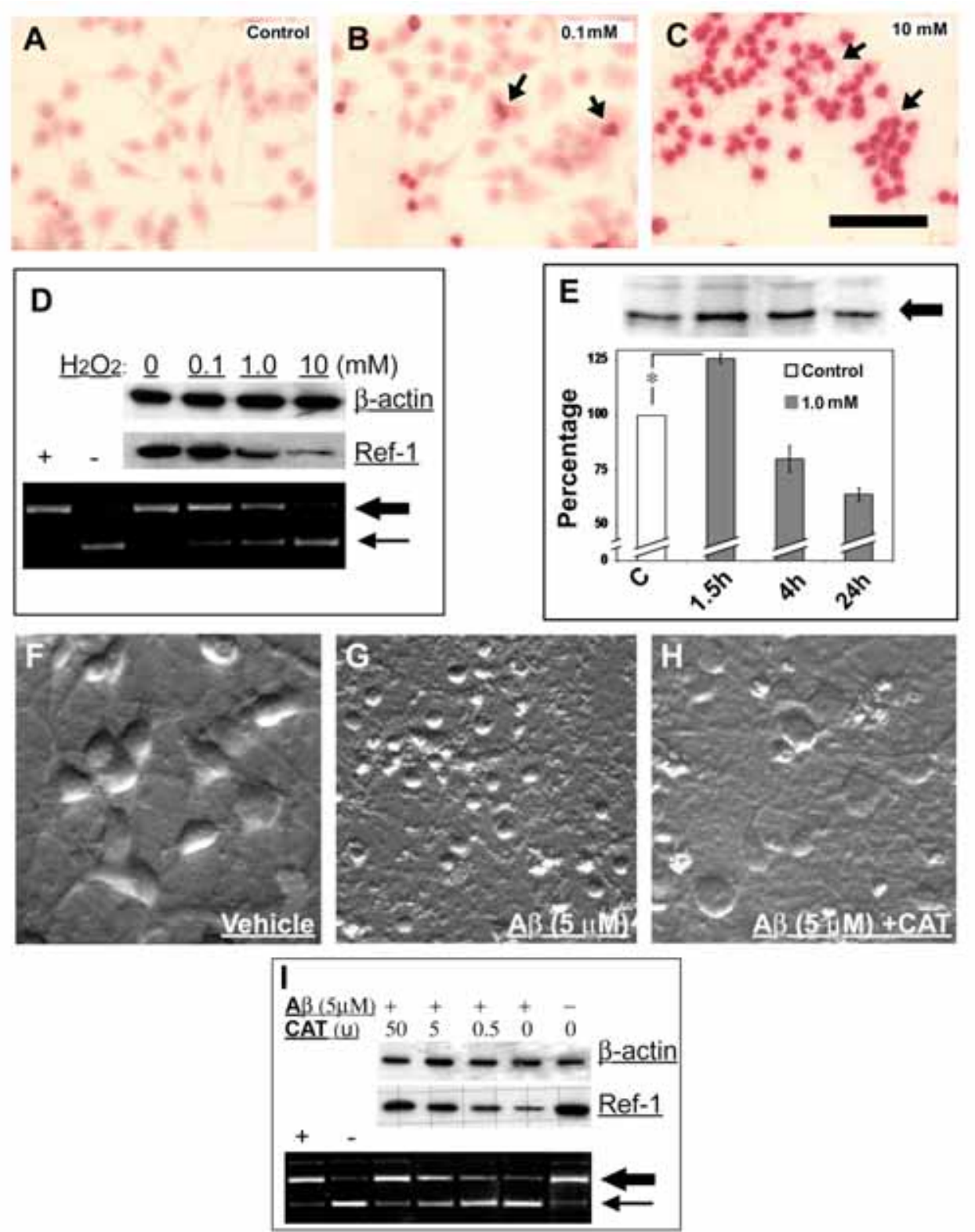

Fig. (4). Dose-dependent effects of hydrogen peroxide on Ref-1 expression and cell survival. (A) TUNEL staining reveals no DNA damage in untreated N2A cells. (B) A small number of cells treated with low dose $\mathrm{H}_{2} \mathrm{O}_{2}(0.1 \mathrm{mM}, 24 \mathrm{hr}$ ) are TUNEL-positive. (C) In contrast, extensive DNA damage occurs following treatment with high dose $\left(10 \mathrm{mM}, 1.5 \mathrm{hr}\right.$ ) $\mathrm{H}_{2} \mathrm{O}_{2}$. (D) Western blotting shows a striking loss of Ref-1 immunoreactivity $1.5 \mathrm{hr}$ after exposure to $10 \mathrm{mM} \mathrm{H}_{2} \mathrm{O}_{2}$. A slight increase and decrease of Ref- 1 immunoreactivity was seen in $\mathrm{N} 2 \mathrm{~A}$ cells $24 \mathrm{hr}$ following treatment with 0.1 and $1 \mathrm{mM} \mathrm{H}_{2} \mathrm{O}_{2}$, respectively. $\beta$-actin was used as a loading control. APE activity assay reveals differential changes in Ref-1 endonuclease activity in neurons after treatment with varying doses of $\mathrm{H}_{2} \mathrm{O}_{2}$. Bold arrow, repaired DNA; thin arrow, unrepaired DNA; +, with saturated control lysates; -, with heat-deactivated control lysates; (E) In contrast, lower dose $(1.0 \mathrm{mM}) \mathrm{H}_{2} \mathrm{O}_{2}$ causes a transient increase in Ref- 1 expression followed by a progressive decrease up to $24 \mathrm{hr}$. The blots were quantified by optical densitometry. Bars represent means $\pm \mathrm{SE}(* \mathrm{p}<0.05 ; * *<0.01, \mathrm{~N}=4$, as per Student $t$-test). (F-H) Differential interference contrast microscopy of neurons treated with vehicle $(\mathbf{F}), 5 \mu \mathrm{M} \mathrm{A} \beta_{1-42}(\mathbf{G})$ or $5 \mu \mathrm{M} \mathrm{A} \beta_{1-42}$ plus 50 units/ml CAT $(\mathbf{H})$. (I) Western blotting $\left(1^{\text {st }}\right.$ and $2^{\text {nd }}$ panels $)$ shows changes in abundance of Ref-1 protein in neurons treated with vehicle or $5 \mu \mathrm{M} \mathrm{A} \beta_{1-42}$ plus varying doses of CAT. $\beta$-actin was used as a loading control. Corresponding changes in APE activity are shown in the bottom panel. Bold arrow, repaired DNA; thin arrow, unrepaired DNA; +, with saturated control lysates; -, with heat-deactivated control lysates; Scale bar $=60 \mu \mathrm{m}$.

and astrocytic accumulation of Ref-1, and colocalization of Ref-1 with $A \beta$ in senile plaques and a subpopulation of cells in the AD hippocampus. While these findings support a connection between Ref- 1 and oxidative stress in AD, the nature of the relationship between Ref- 1 and $A \beta$ remains to be determined. Specifically, regulation of Ref-1 by exoge- nous administration of $\mathrm{A} \beta$, as we have shown here, may be quite distinct from endogenous $\mathrm{A} \beta$ in $\mathrm{AD}$.

In addition to its DNA repair function, Ref- 1 modulates the redox state and DNA binding of key transcription factors including Fos, Jun, NF-kappaB and p53, which have been implicated in AD pathogenesis $[43,45,46]$. Ref-1 may there- 
fore have dual roles in the CNS response to oxidative stress. Specifically, Ref-1 DNA repair function may play an important role in neuroprotection, whereas redox regulation of gene expression may contribute to neuronal cell death. Thus, alterations in the balance between Ref-1 DNA repair and redox functions may be a critical determinant of neuronal survival following oxidative stress. Future studies will need to clarify the relative importance of each of the functions of Ref-1 protein in either the recovery or death of damaged CNS neurons.

In conclusion, we have shown that Ref- 1 is differentially regulated by varying levels of oxidative stress in neurons. Importantly, reduction of Ref-1 expression and activity by high concentrations of ROS-generators were associated with neuronal death, while lower concentrations of ROSgenerators transiently induced Ref-1 expression in association with prolonged neuronal survival. Our results therefore support a neuroprotective role for Ref- 1 following oxidative stress. Additional work is needed to elucidate the relative importance of the dual functions of Ref- 1 in the neuronal injury response, which could lead to new strategies to optimize neurorecovery.

\section{ABBREVIATIONS}

$$
\begin{array}{ll}
\text { Ref-1 } & =\text { Redox factor-1 } \\
\text { A } \beta & =\beta \text {-amyloid } \\
\text { AD } & =\text { Alzheimer's disease } \\
\text { ROS } & =\text { reactive oxygen species } \\
\text { CNS } & =\text { central nervous system } \\
\text { APE } & =\text { apurinic/apyrimidinic endonuclease } \\
\text { DAB } & =\text { diaminobenzidine } \\
\text { FITC } & =\text { fluorescein isothiocyanate } \\
\text { DAPI } & =4 \text { ',6-Diamidino-2-phenylindole } \\
\text { HBSS } & =\text { Hank's balanced salt solution } \\
\text { PBS } & =\text { phosphate buffer } \\
\text { TUNEL } & =\text { TdT-mediated dUTP nick end labeling } \\
\text { RT-PCR } & =\text { reverse transcription-polymerase chain reaction } \\
\text { AEC } & =\text { aminoethylcarbazole } \\
\text { GFAP } & =\text { glial fibrillary acidic protein } \\
\text { EDTA } & =\text { ethylenediaminetetra-acetate } \\
\text { NeuN } & =\text { neuronal nuclear antigen } \\
\text { LDH } & =\text { lactose dehydrogenase. }
\end{array}
$$

\section{AUTHORS' CONTRIBUTION}

ZT conceived of the study, participated in its design, carried out immunohistochemistry experiments, and drafted the manuscript. LS carried out the cell culture, Western blotting and AP assays. SSS participated in the study design and helped to draft the manuscript. All authors read and approved the final manuscript.

\section{ACKNOWLEDGEMENTS}

This study was supported by NIH AG-26637 to Z.T. and an Alzheimer's Association IIRG grant to S.S.S. The brain tissue used in this project was provided by the Institute for Brain Aging and Dementia Tissue Repository at UCI and Alzheimer's Disease Research Consortium at the University of Southern California.

\section{REFERENCES}

[1] Liu H, Colavitti R, Rovira, II, Finkel T. Redox-dependent transcriptional regulation. Circ Res 2005; 97: 967-74.

[2] Kwon YW, Masutani H, Nakamura H, Ishii Y, Yodoi J. Redox regulation of cell growth and cell death. Biol Chem 2003; 384: 991-6.

[3] Kelley MR, Parsons SH. Redox regulation of the DNA repair function of the human AP endonuclease Ape1/ref-1. Antioxid Redox Signal 2001; 3: 671-83.

[4] Evans AR, Limp-Foster M, Kelley MR. Going APE over ref-1. Mutat Res 2000; 461: 83-108.

[5] Ramana CV, Boldogh I, Izumi T, Mitra S. Activation of apurinic/apyrimidinic endonuclease in human cells by reactive oxygen species and its correlation with their adaptive response to genotoxicity of free radicals. Proc Natl Acad Sci USA 1998; 95: 5061-66.

[6] Rothwell DG, Barzilay G, Gorman M, Morera S, Freemont P, Hickson ID. The structure and functions of the HAP1/Ref-1 protein. Oncol Res 1997; 9: 275-80.

[7] Walker LJ, Craig RB, Harris AL, Hickson ID. A role for the human DNA repair enzyme HAP1 in cellular protection against DNA damaging agents and hypoxic stress. Nucleic Acids Res 1994; 22: 4884-89.

[8] Forrester K, Ambs S, Lupold SE, et al. Nitric oxide-induced p53 accumulation and regulation of inducible nitric oxide synthase expression by wild-type p53. Proc Natl Acad Sci USA 1996; 93: 2442-7.

[9] Jayaraman L, Murthy KG, Zhu C, Curran T, Xanthoudakis S, Prives C. Identification of redox/repair protein Ref-1 as a potent activator of p53. Genes Dev 1997; 11: 558-70.

[10] Ono Y, Watanabe M, Inoue Y, et al. Developmental expression of APEX nuclease, a multifunctional DNA repair enzyme, in mouse brains. Brain Res Dev Brain Res 1995; 86: 1-6.

[11] Xanthoudakis S, Smeyne RJ, Wallace JD, Curran T. The redox/DNA repair protein, Ref-1, is essential for early embryonic development in mice. Proc Natl Acad Sci USA 1996; 93: 8919-23.

[12] Dragunow M. Ref-1 expression in adult mammalian neurons and astrocytes. Neurosci Lett 1995; 191: 189-92.

[13] Walton M, Lawlor P, Sirimanne E, Williams C, Gluckman P, Dragunow M. Loss of Ref-1 protein expression precedes DNA fragmentation in apoptotic neurons. Brain Res Mol Brain Res 1997; 44: 167-70.

[14] Vasko MR, Guo C, Kelley MR. The multifunctional DNA repair/redox enzyme Ape1/Ref-1 promotes survival of neurons after oxidative stress. DNA Repair (Amst) 2005; 4: 367-79.

[15] Kawase M, Fujimura M, Morita-Fujimura Y, Chan PH. Reduction of apurinic/apyrimidinic endonuclease expression after transient global cerebral ischemia in rats: implication of the failure of DNA repair in neuronal apoptosis. Stroke 1999; 30: 441-8; discussion 449.

[16] Fujimura M, Morita-Fujimura Y, Kawase M, Chan PH. Early decrease of apurinic/apyrimidinic endonuclease expression after transient focal cerebral ischemia in mice. J Cereb Blood Flow Metab 1999; 19: 495-501.

[17] Gillardon F, Bottiger B, Hossmann KA. Expression of nuclear redox factor ref-1 in the rat hippocampus following global ischemia induced by cardiac arrest. Brain Res Mol Brain Res 1997; 52: 194200.

[18] Edwards M, Kent TA, Rea HC, et al. APE/Ref-1 responses to ischemia in rat brain. Neuroreport 1998; 9: 4015-18.

[19] Tan Z, Sankar R, Tu W, et al. Immunohistochemical study of p53associated proteins in rat brain following lithium-pilocarpine status epilepticus. Brain Res 2002; 929: 129-38.

[20] Tan Z, Sun N, Schreiber SS. Immunohistochemical localization of redox factor-1 (Ref-1) in Alzheimer's hippocampus. Neuroreport 1998; 9: 2749-52.

[21] Nunomura A, Castellani RJ, Zhu X, Moreira PI, Perry G, Smith MA. Involvement of oxidative stress in Alzheimer disease. J Neuropathol Exp Neurol 2006; 65: 631-41. 
[22] Markesbery WR, Lovell MA. DNA oxidation in Alzheimer's disease. Antioxid Redox Signal 2006; 8: 2039-45.

[23] Beal MF. Oxidative damage as an early marker of Alzheimer's disease and mild cognitive impairment. Neurobiol Aging 2005; 26: 585-6.

[24] Mattson MP. Pathways towards and away from Alzheimer's disease. Nature 2004; 430: 631-9.

[25] Tan Z, Sun X, Hou FS, et al. Mutant ubiquitin found in Alzheimer's disease causes neuritic beading of mitochondria in association with neuronal degeneration. Cell Death Differ 2007; 14: 1721-32.

[26] Kaech S, Banker G. Culturing hippocampal neurons. Nat Protoc 2006; 1: 2406-15.

[27] Schnell SA, Staines WA, Wessendorf MW. Reduction of lipofuscin-like autofluorescence in fluorescently labeled tissue. J Histochem Cytochem 1999; 47: 719-30.

[28] Redaelli A, Magrassi R, Bonassi S, Abbondandolo A, Frosina G. AP endonuclease activity in humans: development of a simple assay and analysis of ten normal individuals. Teratog Carcinog Mutagen 1998; 18: 17-26.

[29] Behl C, Davis JB, Lesley R, Schubert D. Hydrogen peroxide mediates amyloid beta protein toxicity. Cell 1994; 77: 817-27.

[30] Qin L, Liu Y, Cooper C, Liu B, Wilson B, Hong JS. Microglia enhance beta-amyloid peptide-induced toxicity in cortical and mesencephalic neurons by producing reactive oxygen species. J Neurochem 2002; 83: 973-83.

[31] Behl C. Amyloid beta-protein toxicity and oxidative stress in Alzheimer's disease. Cell Tissue Res 1997; 290: 471-80.

[32] Seki S, Ikeda $\mathrm{S}$, Watanabe $\mathrm{S}$, et al. A mouse DNA repair enzyme (APEX nuclease) having exonuclease and apurinic/apyrimidinic endonuclease activities: purification and characterization. Biochim Biophys Acta 1991; 1079: 57-64.

[33] Fritz G, Grosch S, Tomicic M, Kaina B. APE/Ref-1 and the mammalian response to genotoxic stress. Toxicology 2003; 193: 67-78.

[34] Vousden KH. p53: death star. Cell 2000; 103: 691-4.

[35] Morrison RS, Kinoshita Y. The role of p53 in neuronal cell death. Cell Death Differ 2000; 7: 868-79.
[36] Onyango IG, Khan SM. Oxidative stress, mitochondrial dysfunction, and stress signaling in Alzheimer's disease. Curr Alzheimer Res 2006; 3: 339-49.

[37] Lee HG, Castellani RJ, Zhu X, Perry G, Smith MA. Amyloid-beta in Alzheimer's disease: the horse or the cart? Pathogenic or protective? Int J Exp Pathol 2005; 86: 133-8.

[38] Smith MA, Richey HPL, Sayre LM, Beckman JS, Perry G. Widespread peroxynitrite-mediated damage in Alzheimer's disease. J Neurosci 1997; 17: 2653-7.

[39] Smith MA, Hirai K, Hsiao K, et al. Amyloid-beta deposition in Alzheimer transgenic mice is associated with oxidative stress. J Neurochem 1998; 70: 2212-5

[40] Pappolla MA, Chyan YJ, Omar RA, et al. Evidence of oxidative stress and in vivo neurotoxicity of beta-amyloid in a transgenic mouse model of Alzheimer's disease: a chronic oxidative paradigm for testing antioxidant therapies in vivo. Am J Pathol 1998; 152: $871-7$.

[41] Schubert D, Behl C, Lesley R, et al. Amyloid peptides are toxic via a common oxidative mechanism. Proc Natl Acad Sci USA 1995; 92: 1989-93.

[42] Valencia A, Moran J. Reactive oxygen species induce different cell death mechanisms in cultured neurons. Free Radic Biol Med 2004 36: $1112-25$

[43] Anderson AJ, Su JH, Cotman CW. DNA damage and apoptosis in Alzheimer's disease: colocalization with c-Jun immunoreactivity, relationship to brain area, and effect of postmortem delay. J Neurosci 1996; 16: 1710-9.

[44] Fishel ML, Vasko MR, Kelley MR. DNA repair in neurons: so if they don't divide what's to repair? Mutat Res 2006; 614(1-2): 2436.

[45] de la Monte SM, Sohn YK, Wands JR. Correlates of p53- and Fas (CD95)-mediated apoptosis in Alzheimer's disease. J Neurol Sci 1997; 152: 73-83.

[46] Kamasani U, Prendergast GC. Genetic response to DNA damage: proapoptotic targets of RhoB include modules for $\mathrm{p} 53$ response and susceptibility to Alzheimer's disease. Cancer Biol Ther 2005; 4: 282-8.

(C) Tan et al.; Licensee Bentham Open.

This is an open access article licensed under the terms of the Creative Commons Attribution Non-Commercial License (http://creativecommons.org/licenses/by-nc/3.0/) which permits unrestricted, non-commercial use, distribution and reproduction in any medium, provided the work is properly cited. 